\title{
Tendenser i idrætshistorisk forskning 1995-2005
}

\section{Af Bo Vestergård Madsen og Niels Kayser Nielsen}

Denne artikel er en forskningsoversigt, som dækker en tiårig periode fra ca. 1995 til i dag. Vi har valgt at sætte fokus på kropskultur, demokrati og folkeoplysning, idet disse emner og deres indbyrdes sammenhæng kan ses som et særligt felt for den idrætshistoriske forskning herhjemme. Der tages altså udgangspunkt i Danmark, men med udblik til de internationale inspirationskilder. For - som vi skal se - har der også været andre tendenser i den danske forskning.

Forskere i Danmark var lang tid om at komme i gang med det idrætshistoriske felt $\mathrm{i}$ sammenligning med f.eks. Sverige, Tyskland og England. Selvom der var spæde tiltag til unders $\varnothing$ gelser af idrætten og kroppens historie i 1970'erne, var der ingen etablerede formidlingskanaler, der kunne indfange de nye strømninger. Først med tidsskriftet Centring fra IdrætsForsk og Den jyske Historikers temanummer om »Sportshistorie « i 1981 begyndte der for alvor at ske noget. Disse tidsskrifter blev i 1982 fulgt op af Ove Korsgaards banebrydende idrætshistoriske oversigtsværk, som - meget sigende - fik titlen Kampen om kroppen. ${ }^{1}$

Samme år udkom Jens Krogslunds første samling af gymnastikhistoriske kilder J.C.F. Gutsmuths og hans samtid. Gymnastik-historiske kilder, bind I med vægten lagt på J.C.F. Gutsmuths. Denne prisværdige indsats for at lette adgangen til læsningerne af de primære kilder blev i 1987 fulgt op med bind II om den lingske gym- nastik i form af værket Nogle rids af Linggymnastikkens for-historie $i$ Danmark. Gymnastik-historiske kilder, bind II. ${ }^{2}$ Interessen for indsamling af kildemateriale $\mathrm{i}$ starten af 1980'erne afspejlede sig også i afholdelsen af det første seminar om idrætshistorie i Danmark, som netop havde dette emne som omdrejningspunkt. ${ }^{3}$

Det konfliktperspektiv, som Ove Korsgaard anlagde i Kampen om kroppen, kom på mange måder til at være anvisende for den kropskulturelle forskning i Danmark, hvad enten man tilsluttede sig eller tog afstand fra Korsgaards "gårdmandslinje $\ll .{ }^{4}$ Bogen var skelsættende i den forstand, at den er et fors $\emptyset \mathrm{g}$ på at »lade historien komme til udtryk i idrætten og den kamp, der til enhver tid foregår om kroppen $\ll .{ }^{5}$ Hovedtesen - og det teoretiske fundament for bogen - var enkel, men givtig: »Ligesom enhver kultur og kulturepoke har en dominerende form for arkitektur, har den en dominerende form for legemskultur $«{ }^{6}$ Idrætten og sporten blev altså her anskuet som specifikke historiske former for legemskultur. Denne grundtanke har stadig gyldighed, ligesom Korsgaards skelnen mellem idræt og gymnastik på landet og sport $\mathrm{i}$ byerne har haft en diskursiv og dagsordensfastsættende status. Det andet store synteseværk vedr. dansk idrætshistorie, nemlig Else Trangbæk m.fl. (red.): Dansk Idratsliv, bd. 1-2 (1997) følger dog ikke Korsgaards optik. ${ }^{7}$ Her vægtes aktiviteter- 
ne, foreningslivet og DIF's rolle i dansk idrætsliv højere.

Som helhed lader dansk idrætshistorisk forskning sig inddele i en række faser. Den første fase (1972-1978) er karakteriseret ved forskellige spæde fors $\varnothing \mathrm{g}$ på at bringe idrætten og kroppen ind i historien. I den anden fase (1978-1982) lykkes det at få udgivet en række tids- og årsskrifter, der sætter emnet på dagsordenen, mens den tredje fase (1982-1990) er præget af udgivelsen af det første samlede værk om idrættens historie i Danmark, egentlige kropskulturelle analyser og lokalhistoriske undersøgelser samt etableringen af en idrætshistorisk årbog. Den fjerde fase (1990-1995) udmærker sig ved, at forskellige kulturanalytiske vinkler for alvor inddrages, mens det idrætshistoriske felt uddifferentieres. I den femte og sidste fase (1995-2005) bliver forholdet mellem krop, folkeoplysning og demokrati for alvor underkastet analytisk interesse, men som vi skal se i det følgende, er der også megen anden forskning på banen, herunder også mere traditionel idrætshistorisk organisations- og foreningshistorie.

Det er den sidste fase, vi her vil se nærmere på. For en behandling af de første fire faser henvises der til Bo Vestergård Madsens forskningsoversigt i ph.d.-afhandlingen Oplysning $i$ bevagelse fra 2003, som fører Niels Kayser Nielsens oversigt fra 1992 i dennes ph.d.-afhandling Fra Robin Hood til fodbold à jour. ${ }^{8}$ - Dog først et par ord om forskningens formelle organer.

\section{Idratshistoriske fora og kanaler}

De formidlingsmæssige organer og kanaler, der savnedes i 1970'erne, kom til i løbet af 1980'erne. I 1985 oprettedes med Else Trangbæk som ivrig forkæmper Dansk
Idrætshistorisk Forening - Krop og kultur, som har til formål »... at $\varnothing$ ge bevidstheden om samspillet mellem idræt og samfund krop og kultur (...) foreningen søger at etablere sig som et aktivt forum for formidling i forskning og debat om idrætshistorie ${ }^{9}{ }^{9}$ Med inspiration fra Svenska idrottshistoriska föreningens årbog Idrott, historia och samhälle, som startede i 1981, kom den danske idrætshistoriske årbog også til i 1985. Følgelig kunne både den idrætshistoriske forening og årbogen i 1995 fejre 10års jubilæum. Det gav anledning til, at man både internt og eksternt kunne gøre status. Nordisk idrætshistories nestor, professor i idrætshistorie ved Historiska Institutionen ved Stockholms Universitet, Jan Lindroth, gav sit bud på de linjer i dansk idrætshistorisk forskning, som årbøgerne har tegnet, ved at påpege, at gymnastikhistorien havde fået en central placering, mens den urbane konkurrencesport var mindre udforsket. Her havde man ifølge Lindroth "gått runt dette tema som katten kring hett gröt $\ll .{ }^{10}$ Lindroth pegede desuden på, at situationen i Sverige var nærmest omvendt. Her havde den urbane sport haft højere prioritet end Ling-gymnastikken og dens udvikling. Lindroth beklagede også, at forskningen ikke i højere grad havde beskrevet den danske, pluralistiske idrætsorganisering, herunder dens opståen og lange udviklingslinjer. ${ }^{11}$ I Danmark har man ifølge Lindroth foretrukket at gå direkte til idrættens manifestationer og ikke om- eller genvejen over idrætsorganisationerne. Lindroth pegede dog selv på det bredt anlagte, historiske projekt om den moderne idræts historie i Danmark, som i anlednings af DIF's forestående 100-års jubilæum resulterede i det føromtalte værk Dansk Idratsliv bd. 1-2. Som vi skal se i det følgende, er der dog i vid udstrækning rettet op på denne manko. 


\section{Forskning i idratsorganisa- tioner og institutioner}

Således trak Jørn Hansens bidrag i det bind af Idrcetshistorisk Årbog, der blev sendt på gaden i 1995, i et historisk essay hovedlinjerne op omkring organisationernes historie og udvikling. ${ }^{12}$ Det blev fulgt op af Ib Nordbys bog Sablen og den blode hat fra 1995 om forholdet mellem organisationernes formål og politiske praksis. Med udgangspunkt i DDSG\&I belyste Nordby organisationens idégrundlag og den politiske praksis i krigsårene 1940-1945. Nordby påpegede, at DDSG\&I's formålsparagraf - »Foreningens formål er gennem sine virkemidler at skabe en vågen og sund dansk ungdom «i 1941 fik en vigtig tilføjelse, som geninstallerede forsvarsdimensionen: »... til styrkelse af fædrelandskærligheden og forsvarsviljen i folket $\ll .{ }^{13}$ Denne ideologiske manifestation afspejlede sig dog ikke i organisationens praksis i krigsårene, hvor man bl.a. undslog sig for at underskrive en protestskrivelse mod jødeforfølgelserne i 1943 og undlod at engagere sig i det illegale modstandsarbejde. Bogen beskrev desuden formanden for DDSG\&I, Arnth-Jensens opbakning til Niels Bukhs forsøg på at samle ungdomsarbejdet i Danmarks Ungdomsforbund, mens man efter denne idés kuldsejling afviste at gå ind i Dansk Ungdomssamvirke, der med Hal Koch i spidsen ville styrke det demokratiske aspekt $i$ ungdomsarbejdet. Ib Nordbys bog, som også indeholdt en fyldig redegørelse for den historiske baggrund, var et solidt og grundigt studium med netop organisationen i centrum, som Lindroth efterlyste. Den gik ind bag festtalerne og de store ord og konfronterede »siger « og »gør« med hinanden. Derved fik Nordby sat et alvorligt spørgsmålstegn ved den nationale mytedannelse om krigens tid og idrætsorganisationernes rolle heri.
Et andet stykke gymnastikinstitutionshistorie stod Klara Aalbæk Korsgaard for med bogen Anna og Jørgine fra 1996, som undersøgte Snoghøj Gymnastikhøjskoles historie - den første gymnastikhøjskole for kvinder - med de to forstandere, Jørgine Abildgaard og Anna Krogh, i centrum. ${ }^{14}$ Trods den beskedne beskrivelse af bogen som en »historisk fortælling « fik Aalbæk Korsgaard gennem stor indlevelse beskrevet et unikt kapitel i (kvinde)gymnastikkens historie i Danmark. Det var Anna Kroghs og Jørgine Abildgaards højskolehistorie fra 1925-1958, der blev fortalt, men historien havde også eksemplarisk karakter og blev derved et bidrag til den folkelige gymnastiks historie med personlighederne i centrum. Aalbæk Korsgaard berettede om såvel skolens opstart og hverdagsliv som de faglige og personlige kampe, som forstanderparret var en vigtig del af. Skolen var unik derved, at den var den første (og sidste) af sin art, og den skilte sig også ud gennem de arkitektoniske og åndelige gestaltninger. I $1933 \mathrm{blev}$ der tilføjet en kirke til selve højskolebygningen, som dermed kom til at samle de fire sale: gymnastiksalen, foredragssalen, spisesalen og kirkesalen. Hermed trådte skolens værdigrundlag frem, idet man både vægtede det kropslige, det åndelige, det hjemlige/ verdslige og det religiøse, som især Jørgine Abildgaard var eksponent for. Gymnastisk var Anna Krogh og Jørgine Abildgaard præget af finske Elli Björksténs poetiske og formgivende kvindegymnastik, som skulle demonstrere »en Sjolens Kraft $\ll .{ }^{15}$ Nok havde gymnastikken et fysiologisk og anatomisk udgangspunkt, men den skulle hvile på et æstetisk og opdragende grundlag. »Åndeligheden « i Snoghøjernes univers byggede både på et kristent og nationalt indhold, der blev knyttet til den kropslige manifestation. I ligevægtsstillingerne skulle pigerne vende kroppen mod det sønderjyske land. 
Netop den sønderjyske og sydslesvigske idræts organisationshistorie har Jørn Hansen i den forløbne periode efter 1995 ved gentagne lejligheder beskæftiget sig med. Centralt i denne forskning står værket Ikke at syne, men at vare. Sønderjydsk idrat gennem 100 år fra 2003, der er mere end blot et jubilæumsskrift. ${ }^{16}$ Med fokus på de danske gymnastik- og ungdomsforeninger i grænselandet tegner forfatteren et billede af det organisatoriske arbejde i landsdelen. I forlængelse heraf behandles spørgsmålet om idrættens politisering og funktion i det nationale spørgsmål, hvor Jørn Hansen, yderst nøgternt, er tøvende med hensyn til at tillægge idrætten en primær rolle på dette felt.

Verner Bruhns bog Det skceve tra. Trak af ungdomsforeningernes og gymnastikforeningernes historie efter 1945 skal også nævnes i denne sammenhæng som et solidt stykke organisationshistorie, der med sine studier af de kulturelle dimensioner af det praktiske liv også bidrager til demokratiets historie i det civile samfund. ${ }^{17}$ Vægten er lagt på tiden efter 1945, hvor både De danske Gymnastikforeninger (DDG), De danske Ungdomsforeninger (DDU) og De Danske Skytte-, Gymnastik- og Idrætsforeninger (DDSG\&I) behandles og ses i en sammenhæng, hvilket giver folkeoplysnings- og demokratispørgsmålet tyngde. Bogen belyser organisationernes historie ud fra to overordnede synsvinkler. Dels belyses landsforeningernes interne forhold, hvor der stilles skarpt på det specielle danske organisationsbillede og problemerne med sammenslutningerne i 1965 (DDGU) og 1992 (DGI), dels anskueligg øres de eksterne forhold, dvs. de samfundsmæssige forskydninger og deres politisk-kulturelle betydning for organisationerne. Det er netop ligevægtningen af disse synsvinkler, der trods det skæve udgangspunkt giver fremstillingen et helstøbt præg.
Per Jørgensens ph.d.-afhandling Ro, renlighed, regelmassighed. Dansk IdratsForbund og sportens gennembrud ca. 1896-1918 drejer sig, som titlen angiver, også om organisationshistorie. ${ }^{18}$ Afhandlingen har bl.a. sin styrke i integrationen af teori og empiri, hvor Michel Foucault og især Norbert Elias anvendes til perspektivering af et bredt og varieret kildemateriale. Med denne afhandling har DIF's første årtier, hvor man primært var hjemmehørende i det københavnske borgerskab, fået sit værk. Desuden er afhandlingen et godt eksempel på, hvor nyttig teoriinddragelse er til forståelse af idrætsverdenen. Tilsvarende svenske studier i den tidligste idræt i Stockholm savner, trods den kildemæssige akribi og forskningsmæssige soliditet, i nogen grad dette løft.

Også skoleidrætten har fået sin grundige behandling i antologien »Een Time dagligen « - skoleidrat gennem 200 år ${ }^{19}$ Bogen udkom i 1998 i anledning af 100 året for oprettelsen af det »Et-aarige Gymnastikkursus under Statens Lærerkursus«, som startede i september 1898 med tretten kvinder og ni mænd. Det er skoleidrætten, der er i fokus, og forfatterne søger at belyse udviklingslinjerne fra den tidlige indførelse af gymnastikfaget i almue- og borgerskolerne i 1814 til vore dages idrætsundervisning. Antologien viser, at diskussionerne om dette fag afspejler de vekslende betydninger, man har tillagt idrætten i forhold til børn og unges dannelsesproces. Også i dag er faget spændt ud mellem politisk og pædagogisk velvilje på den ene side og en konkret nedvurdering på den anden side. Når »fagligheden « i skolen skal styrkes, må idrætten træde tilbage. Antologien anskueligg ør, at begrebet idræt skifter betydningsindhold over tid ligesom begrebet skole. Derved gives et indblik i faget særstatus og særlige kampfelt. Der er mange, 
der går til frivillig idræt efter skole, men ikke mange, der dyrker frivillig matematik.

Den olympiske bevægelse tages under behandling i bogen Ringene samles (2004) af Jørn Hansen. ${ }^{20}$ Dermed følges der op på temaet for Idrætshistorisk årbog 2003, hvor temaet netop var de moderne Olympiske Lege. I et ligefremt sprog søger Jørn Hansen at fremstille en sammenhængende fortælling om denne sportsfest, der tidligt lå i skyggen af de store verdensudstillinger, men som efterfølgende blev til den massive begivenhed, vi kender i dag. Undervejs berettes om bl.a. IOC's selvsupplerende organisationsform og den noget tvetydige holdning til de totalitære politiske strømninger og regimer i historien. Bogen er den første samlede fremstilling af den olympiske bevægelses historie.

Idræt og organisationshistorie er ligeledes temaet i Ole Skjerks ph.d.-afhandling Dameudvalgets inderlige Overfl $\phi$ dighed fra 2001, der grundigt og veldokumenteret undersøger synet på damehåndbold i de folkelige hovedorganisationer DDS, DDG og DDSG\&I i tiden 1900-1950. ${ }^{21}$ Hovedsagelig er det de formelle og organisatoriske rammer omkring og begrundelser for at spille damehåndbold, der behandles, medens selve udførelsen ikke tematiseres synderligt. Skjerks afhandling retter således også op på de mangler, Jan Lindroth indirekte påpegede i 1995. Samtidig er den et godt eksempel på styrken i komparative analyser, der også inddrager kønsaspektet.

Netop dette sidste står også stærkt i etnografen Sine Agergaards ph.d.-afhandling At viderefфre traditionerne fra 2004, der sammenligner traditionsforvaltning og innovation i to danske idrætsmiljøer, nemlig Gymnastik- og Idrætshøjskolen ved Viborg med rod i det grundtvigianske folkelige arbejde og Danmarks Trænerskole Aalborg med DIF som bagland. ${ }^{22}$ Skønt også organisationsmæssigt anlagt er det i højere grad den kropslige lighed og forskel i praksis, fx ritualer, hverdagsliv og adfærd, der her undersøges. Afhandlingen er et godt eksempel på, hvorledes en anden videnskabelig tilgang end den historiske, kan kaste nyt lys på idrætshistorie og brugen af historien. Her er banet nye veje.

\section{Lokalhistorie og idrat}

Medens Jørn Hansen i Idrætshistorisk Årbog 1994 (udkom 1995) tog sig af det organisationsmæssige perspektiv, gik Niels Kayser Nielsen en anden vej med en række artikler i bl.a. Magasin fra det kgl. Bibliotek og Fortid og Nutid. ${ }^{23}$ Ved at foretage en række lokalhistoriske studier i sporten og gymnastikken på foreningsplan i mellemkrigstiden viste han, at opfattelsen af en skarp opdeling af provinskultur med gymnastik og bykultur med sport ikke holder ved et nærmere eftersyn. Denne inddeling af både idrætslig og politisk-kulturel art, som især Ove Korsgaards bog Kampen om kroppen havde bidraget til, var ifølge Kayser Nielsen blevet brugt til »cementeringen af det politisk-organisatoriske modsætningsforhold mellem på den ene side DDGU (DGI) og på den anden side DIF « ${ }^{24}$ Kayser Nielsens tese var, at netop på landet, hvor modsætningsforholdet skulle være mest prægnant, var der snarere tale om et suppleringsforhold mellem de to idrætsformer.

Til at belyse dette fokuseredes der på især tre forhold. For det første havde højskolerne ikke et så anstrengt forhold til sporten, som det ellers er blevet hævdet. Med udgangspunkt i et af højskolebevægelsens arnesteder, Askov Højskole, kunne det vises, at der var et udbredt samarbejde mellem skolen og det private erhvervsliv i Vejen, som bl.a. kom til udtryk i samarbej- 
de om både sporten og gymnastikken. For det andet fremdrog Kayser Nielsen DIF's støtte til Niels Bukh i 1920'erne, hvor man bl.a. samarbejdede med DDSG om kurser, og hvor DIF støttede opførelsen af Gymnastikhøjskolen i Ollerup. For det tredje kunne man se, at afhængigheden mellem sporten og gymnastikken syntes udtalt i idrætslivets hverdag i starten af 1930'erne, hvor der var tale om en foreningskrise, der især truede gymnastikken. Niels Kayser Nielsen pegede her på, at sportsaktiviteterne mange steder simpelthen reddede gymnastikforeningerne fra nedlæggelse. Med disse lokalstudier kan der tegnes et mere nuanceret hverdagsbillede af idrætslivet, som det udfoldede sig trods de organisatoriske skel og ideologiske modsætninger. Poul Porskær Poulsens artikel: »Det var Ungdom og Kræfter, Styrke og Vilje« gymnastik og skyttesag på Silkeborg-egnen og i Gødvad ca. 1868-1930« fra 1996 er et godt eksempel på, at den lokalhistoriske forskning er et nyttigt korrektiv til den landsdækkende, hvor der på lokalt plan kan dukke afgørende nuanceringer op. ${ }^{25}$ Således dokumenteres det i artiklen, at gymnastikken tidligt var voldsomt konkurrencepræget. Overgangen til svensk gymnastik omkring århundredskiftet 1900 betød ganske vist en svækkelse af fokuseringen på enkeltmandspræstationer, men der kunne dog fortsat uddeles medaljer til enkeltpersoner, ligesom kontant honorering i form af præmier som pibe, pung og bog også fandt sted. Og i kampen om godord og ære og venlige bedømmerord var holdkonkurrencen ingenlunde bandlyst. Gymnastikken omkring århundredskiftet 1900 kendte i rigt mål til præstation og konkurrence, viser Poul Porskær Poulsen, som i $\emptyset$ vrigt også har beskrevet træk af den lokale idræt i Vejle. ${ }^{26}$

Den lokalhistoriske dimension er i den periode, der her behandles, blevet fulgt op på forskellig vis. En række universitetsspecialer har beskæftiget sig hermed, hvor der bl.a. kan peges på Vibeke Høy Worms om den offentlige badeanstalts etablering $\mathrm{i}$ Odense og Helle Iversens om byplanlægning og de ældste idrætsanlæg i Århus, begge indleverede ved Institut for Idræt, SDU. Derudover kan nævnes to specialer fra Historisk Afdeling, AU, nemlig Mads Elleberg Pedersens om holdning til doping i dansk cykelsport 1959-2001 og Steen R. Lundbyes om de tidligste idrætsudøvere i Århus, hvor det som noget helt nyt vises, at det ikke var klassemæssige og sociale faktorer, der var bestemmende for, om og i givet fald med hvem man dyrkede idræt, men derimod geografiske og bopælsmæssige forhold: boede man i opgang med eller på samme gade som en idrætsudøver, var chancen for, at man kom til at dyrke idræt i samme klub ulige større.

Af større lokalhistoriske monografier påkalder Johnny Wøllekærs studie Odense i bevagelse - strejftog i byens idrctshistorie fra 2001 sig særlig opmærksomhed ved sin grundighed og sin sikre omgang med kildematerialet, der er brugt med både varsomhed og overblik, således at Wøllekær ikke falder i den snare, som ellers nok kan true sådanne fremstillinger, at man lader kilderne styre arbejdet. ${ }^{27}$ Bogen er bredt anlagt og fortæller på en og samme gang idrættens og byens historie i tekster og billeder. Wøllekær har desuden bidraget med en række andre lokalhistoriske studier til bl.a. Odensebogen og Idrcetshistorisk Arbog.

I 2002-udgaven af sidstnævnte var temaet lokalhistorie og idræt, som det nok vil være læserne bekendt. I sin præsentation af bogen i Vartov april 2003 pegede Verner Bruhn på, at der på dette område forestår uhyre meget: så snart man finder svar på én problemstilling, rejser der sig to 
nye. Samme Verner Bruhn arbejder i øjeblikket med en undersøgelse af idrætshistorien i et pionér samfund som Esbjerg. Den må man se frem til med megen forventning, for så vidt som lokale undersøgelser har det med at ændre vedtagne opfattelser. Heller ikke den idrætshistoriske kæde er stærkere end det lokale led.

Også derfor er Morten Mortensens nyligt udkomne ph.d.-afhandling Idrat som kommunal velfard. Mentalitet, velfard og idratspolitik i Kobenhavn, Ballerup og Skive 1870-1970 et kærkomment bidrag. ${ }^{28}$ En af Morten Mortensens teser er, at velfærdstanken - forestillingen om det $»$ det gode liv « - og den idrætslige udmøntning heraf først og fremmest har foldet sig ud i lokale, kommunale sammenhænge. Her peger forfatteren på, at idrætsområdet i modsætning til fritids-, social- og kulturområdet ikke har været underlagt en egentlig offentlig styring. Der har generelt været en decideret modvilje mod en samlet målbevidst idrætspolitik i kommunerne. Idræt var jo godt og sundt, så det var der ingen grund til at skændes om. Morten Mortensen afdækker gennem et stort kildemateriale de mentalitetshistoriske spor, som fulgte idrættens udbygning gennem hundrede år. Det gør ham i stand til at påpege de ændringer og kampe, der alligevel fandt sted samtidig med, at det særlige miljø omkring idrætten var relativt stabilt. Her kunne man mødes og skabe personlige netværk både som udøver, leder og politiker. Idrætsmiljøet blev tillagt positive værdier - engagement og social ansvarlighed - og blev dermed et symbol på og indøvelse i velfærdsmoderniseringen. Sluttelig peges der på, at fritidsloven i 1968 blotlagde nogle af de paradokser, der har omgivet - og omgiver - den frivillige idræt. Loven var på den ene side en anerkendelse af foreningsledernes frivillige arbejde og på den anden side en trussel for det. Opfattel- sen af det frivillige arbejde som værende af en særlig utopisk værdi stødte her sammen med et velfærdspolitisk ønske om at højne kvaliteten af fritidslivet. At betale sig til det gode liv i fritiden var et velfærdspolitisk instrument og rationale, der i nogen grad kom i karambolage med den traditionelle opfattelse af det frivillige idrætsarbejde som uegennyttigt og autonomt. Det er en problemstilling, der ikke mindst bliver aktualiseret i disse år, hvor befolkningens sundhedstilstand har stor politisk bevågenhed ikke mindst finansielt. Kan sundhedsfremme og frivillighed gå hånd $\mathrm{i}$ hånd? Tja, gadehjørnet har reddet mange unge fra idrætten, som Jytte Abildstrøm og Niels Hausgaard har udtrykt det. ${ }^{29}$

\section{Idraet og politik}

Som det tredje hovedtræk i den idrætshistoriske forskning 1995-2005 kan man pege på forholdet mellem idræt og politik. Her rager ét værk op blandt alle andre, nemlig Hans Bondes disputats om Niels Bukh fra 2001. ${ }^{30}$ Fortjent har værket fået en voldsom omtale og pressedækning som kronen på mange års arbejde. Debatten herom vil nok være de fleste bekendt. Det væsentlige heri forekommer at være den diskussion, der gjorde sig gældende ved disputatsforsvaret, og som siden har kunnet følges i tidsskriftet Historie, mellem Bonde og 1. opponent John T. Lauridsen. ${ }^{31}$ Det drejer sig om styrken og omfanget af den trusel i retning af fascisering, som Bukh og hans gymnastikbevægelse udgjorde. Bonde mener, at denne trusel i høj grad var til stede. Lauridsen vil nedtone den og gør gældende, at der var andre og farligere folk på den yderste højrefløj i 1930'erne. Denne interessante og væsentlige debat er i nogen grad blevet tilsidesat af de mere sensationelle træk, som især dagspressen og gamle Ollerupianere i bl.a. Ung- 
dom og Idrcet har hæftet sig ved. Udlægninger af Bukhs seksuelle orientering har fået megen spalteplads. Det er Hans Bonde nu ikke selv uden skyld i. Dels er det »godt stof «, dels har forfatteren argumenteret for, at der var en sammenhæng mellem Bukhs homoerotiske syn på kroppen og udformningen af den primitive gymnastik. Også Hans Bonde har måttet erkende, at når der pilles ved sakrosankte myter, ikke mindst dem, der har med besættelsestiden at gøre, falder der straks mytologiserende brænde ned. Ét af de mere betydelige aspekter ved disputatsen er i øvrigt, at Bonde får vist sammenhængen mellem mellemkrigstiden og besættelsestiden, i stedet for, som det ofte ses, at lægge en cæsur ind ved 9. april 1940. I kraft heraf har hans arbejde perspektiv ud over det rent idrætsfaglige. Samtidig blotlægger Bondes biografiske arbejde et uudforsket felt, nemlig det komparative: Hvordan var receptionen af nazismen og fascismen generelt i mellem- og efterkrigstidens gymnastikmiljø? Den biografiske tilgang har haft stor gennemslagskraft i offentligheden, men en komparativ ansats ville givetvis gøre os klogere på perioden og forholdet mellem 1930'ernes totalitære strømninger, grundtvigianismen og gymnastikmiljøet. ${ }^{32}$

Det politiske aspekt er også til stede i den forskningsretning, der eksplicit behandler relationerne mellem idræt og $k ø n$. Else Trangbæk giver bl.a. mæle til dette område i artiklen $\gg$ Gender in Modern Society: Femininity, Gymnastics and Sport « i temanummeret The Nordic World fra serien Sport in Global Society (1998), som også tæller danske bidrag fra Jørn Hansen og Per Jørgensen. ${ }^{33}$ I artiklen forfægter Else Trangbæk det synspunkt, at sportens individuelle konkurrenceorientering og gymnastikkens fokus på den kollektive sammenhængskraft ikke mindst har betydning for, hvordan kønnet konstrueres, og hvordan det i dette tilfælde feminiseres. Hun påpeger her, at hvor den svenske gymnastik blev anset som en passende kulturel ramme for kvindek $\varnothing n n e t$, udgjorde sportens rum et større problem. Gennem gymnastikkens sundhedsbegreb kunne kvindek $\varnothing n n e t$ italesættes som et (særligt) biologisk væsen, hvis kropslige udfoldelse måtte fremelske de husmoderlige dyder, mens sportens grænsesøgende karakter gjorde det vanskeligt på samme vis at formog normsætte kønnet. ${ }^{34}$ Ole Skjerk og Anne Lykke Poulsen har på forskellig vis arbejdet videre med dette tema. ${ }^{35}$ Sidstnævnte er på trapperne med en ph.d.-afhandling om kvindegymnastikken i Danmark 1900-1940 med fokus på kvindelighed, medborgerskab og professionalisering. Lykke Poulsen har dog allerede givet smagsprøver på afhandlingen, senest i Dansk Sociologi (2004) om gymnastiklærerindernes betydning i den nævnte periode. ${ }^{36} \mathrm{Ud}$ fra Bourdieus feltbegreb gør hun sig til talskvinde for, at kvindegymnastikken var relateret til to andre felter, det videnskabelige og det pædagogiske, men også et »skyggefelt « for medborgerskab. Dermed antyder Anne Lykke Poulsen, at kvindegymnastikken ikke blot var et formbart redskab til at fastholde »det feminine «, den indfældede orden, men at den også bidrog til at modernisere kønnet. Erfaringen med gymnastikken og organiseringen af den gav kvinderne mod til at stå på egne ben også i den offentlige sfære. Studiet kan dermed ses som en empirisk fordybelse $i$ et de centrale temaer, som Else Trangbæk gennem årene har sat på den idrætshistoriske dagsorden.

I forlængelse af dette skal også nævnes et nyligt indleveret speciale ved Center for Kulturstudier, SDU, om modtagelse af Medau-gymnastikken i Danmark 1936-1941 af Birgit Brink Lund. Hun analyserer dette sparsomt udforskede emne ud fra den tese, 
at modstanden fra især den folkelige del af gymnastikmiljøet må ses som en kamp om at definere kønnet. Medau-gymnastikkens totalbevægelser og fokus på bækkenet truede med at gøre $\varnothing$ velserne for sanselige. Modstanden kom ikke mindst fra de kvindelige ledere fra landet, som ikke opfattede bevægelserne som frigørende, men derimod seksualiserende, dvs. ukontrollerbare og forførende.

Som noget nyt i perioden 1995-2005 aftegner der sig som helhed en tendens til, at idrætten ikke længere anses som et studieobjekt i sig selv. Det synes at være centralt for den idrætshistoriske forskning, som den kommer til udtryk i forbindelse med idræt og politik, at idrætten anskues som en del af både velfærdssamfundets opbygning og »nation building «. Det gælder ikke mindst forskningen i idrætshistorien i mellemkrigstiden. Den danske forskning på dette felt er vel ikke så udfoldet som i Norge og Sverige, hvor i det første tilfælde Rune Slagstads bog De nasjonale strateger om dannelse, politik og traditionsforvaltning i Norge også indeholdt en idrætshistorisk dimension, som bl.a. Matti Goksøyr har taget op til diskussion. ${ }^{37}$ For Sveriges vedkommende må man for de senere års vedkommende pege på Johan Norbergs afhandling Idrottens väg till folkhemmet - studier i statslig idrottspolitik 1913-1970..$^{38}$ Til gengæld udviser den danske forskning så en mere markant profil i anden sammenhæng, der her præsenteres som den fjerde og sidste tendens, nemlig kropskultur, demokrati og folkeoplysning.

\section{Krop, folkeoplysning og demokrati}

Ikke mindst fra 1997 kom der i højere grad end tidligere fokus på forholdet mellem det tavse og det talte set i relation til folkeop- lysningstraditionen og demokratidiskussionen, som for alvor blussede op og fik forskningsmæssig tyngde. Temaet havde dog været berørt før bl.a. i artiklen »Nationalism and the Culture of the Body: The Politicization of »Popular « Gymnastics in the Nineteenth-Century Denmark « af Henning Eichberg fra periodens start i 1995. ${ }^{39}$

Tre større forskningsprojekter om demokratiets vilkår blev etableret i 1997. Først og fremmest blev den danske magtudredning sat $\mathrm{i}$ gang det år efter en betænkning fra udvalget $»$ vedrørende en analyse af demokrati og magt i Danmark «, nedsat af Folketinget i 1994. Ligeledes blev »Demokratiprojektet « ved Institut for Statskundskab, Københavns Universitet, igangsat under en treårig tidsramme, og endelig fik Forskningscenter for Voksenuddannelse på Danmarks Lærerhøjskole og Center for Kulturstudier på Odense Universitet midler til at gennemføre et fireårigt forskningsprojekt under titlen »Voksenuddannelse, folkeoplysning og demokrati«. Det var således ikke kun en internt idrætshistorisk bevægelse, der var sat i gang. Udslagsgivende blev også bekymringen over ændringerne i demokratiets stilling, hvor sammenhængen med oplysning og deltagelse i traditionelle demokratibærende institutioner - politiske foreninger, fagforeninger $\mathrm{mm}$. - var under opbrud.

I 1997 udkom ligeledes Ove Korsgaards bog Kampen om lyset. Dansk voksenoplysning gennem 500 år, der beskrev de lange linjer i dansk folkeoplysnings historie med fokus på fem »oplysnings- og dannelsestraditioner «: kristen oplysning, statsborgerlig oplysning, folkelig-national oplysning, arbejderoplysning og personlig oplysning. ${ }^{40}$ Selvom kampbegrebet går igen fra Kampen om kroppen, er der ved første øjekast ikke megen krop i dette bredt anlagt værk. Korsgaard vælger i stedet at se oplysningshi- 
storien ud fra tre indfaldsvinkler, der belyser idégrundlaget, institutionsgrundlaget og fag/medie/metodegrundlaget: en idéhistorisk, en institutionshistorisk og en didaktisk. Trods vægtningen af »det talte «- eller netop pga. denne vinkling - kommer forholdet mellem krop, demokrati og folkeoplysning op til overfladen. Korsgaard bemærker i slutningen af bogen, at kroppen i det postmoderne samfund i højere grad bliver frigjort fra den materielle produktion for at blive inddraget i den kulturelle produktion: »Kroppen betragtes ikke længere som en beholder, der skal fyldes med »ånd «, men anskues i stigende grad som en basis for al videns-, erfarings-, og identitetsdannelse. Udviklingen af autentiske, ikkesproglige oplevelser, fornemmelser og erfaringer bliver en helt anderledes central opgave end tidligere. I dette perspektiv bliver praktisk-æstetisk virksomhed ikke et sekundært element i uddannelsespolitikken, men af vital betydning $\ll{ }^{41}$

Spørgsmålet om kroppens og ordets betydning for demokratiet behandles mere eksplicit i Korsgaards betydningsfulde artikel »Delingsføreruddannelse og demokratiuddannelse « fra 1997. ${ }^{42}$ Her sammenligner han delingsføreruddannelsen i gymnastik på højskolerne med lederuddannelsen på Krogerup, som med Hal Koch i spidsen fors $\emptyset$ gte $»$ at skabe forbindelse mellem det folkelige og det politiske...«, dvs. bibringe kommende ungdomsledere demokratisk dannelse. ${ }^{43}$ I modsætning til delingsføreruddannelsen blev Hal Kochs demokratiuddannelse ingen succes, og han forlod Krogerup Højskole i $1956 .{ }^{44}$ Det er forståeligt - bemærker Korsgaard - at Hal Koch på baggrund af historiske erfaringer fra mellemkrigstiden og de første besættelsesår trak en skarp linje mellem »ordet « og »Sværdet «: »Problemet med en sådan demarkationslinje er imidlertid, at en stor del af det æstetiske felt glider ud af syne. Sat på spidsen er spørgsmålet, om man med sværdet kan kæmpe en symbolsk kamp, der i æstetisk form svarer til den ordkamp, som demokratiet har som forudsætning? Findes der en demokratisk konfiguration af magten, der kan fremstilles symbolsk? Eller er demokrati principielt forbundet med taletilbud og billedforbud? «. ${ }^{45}$ Korsgaard antyder selv et svar: »selv om der klart er en spænding mellem demokrati og æstetik, kan demokratiet sikkert ikke undvære den kraft, der kan ligge i æstetikken, hvor tvetydigt den end kan være «. ${ }^{46}$ Niels Kayser Nielsen tager diskussionen om krop og tale op i artiklen $\gg$ Kroppen som demokratisk anliggende - i en nordisk kontekst « fra tidsskriftet Historie (2002), som byder på en anden læsning af Hal Koch. ${ }^{47}$ Her peges der på, at der i 1930'erne kan spores en ny demokratiopfattelse, hvor de universalistiske frihedsrettigheder, baseret som de var på et abstrakt individ, kombineres med den konkrete krops sociale behov.

En anden artikel, der på afgørende vis belyser forholdet mellem krop og demokrati, er Henning Eichbergs »Otherness in Encounter. Thinking Folk Identity, Democracy and Civil Society with the Help of Martin Buber « fra 1997..$^{48}$ Eichberg nærmer sig problemstillingen fra en anden vinkel, idet han tager udgangspunkt $i$ to definitioner på demokrati for herefter - i den velkendte trialektiske stil - at give et tredje bud. Dels peger han på den demokratiforståelse, der sætter fokus på den skrevne forfatning. Det er her ikke blot et spørgsmål om nedfældede regler - ofte er forfatningen genstand for stor veneration og ses som nationens sjæl, der kræver patriotisk »kærlighed «. En anden forståelse retter sig mod reglerne og reguleringen af valg og repræsentation. Demokratiet ses her som et sæt regler, der regulerer, hvordan en regering kan skiftes ud 
eller genvælges på baggrund af en formalisering af folkets røst. Fokus er her på selve valghandlingen og de regler, der afstemmer den politiske indflydelse. Ifølge Eichberg er den danske demokratiforståelse karakteristisk derved, at den ikke definitivt lægger sig op ad den ene eller den anden af disse tolkninger. På den ene side værdsættes de demokratiske rettigheder, der er nedfældet $\mathrm{i}$ grundloven - herunder f.eks. forsamlingsfriheden - og på den anden side tages de formelle regler om stemmeafgivelse og repræsentation meget alvorligt, men det er ikke hverken konstitutionen eller valghandlingen, der anskues som kernen i demokratiet. På baggrund af det levede liv, som det historisk set har udfoldet sig i idrætsverdenen og i foreningslivet, anskues demokratiet snarere som en samfundsmæssig praksis, hvor selvbestemmelsen og den frivillige organisering udfolder sig mellem valgene. Gennem læsning og udlægning af filosoffen og teologen Martin Bubers begreber om »Jeg «, »Du« og »Det « karakteriserer Eichberg de to første demokratiforståelser som vigtige, men tingsliggjorte størrelser (tilhørende »Det «-verdenen), der er udkrystalliseringer af det egentlige: Det levende demokrati, dvs. folks evner og muligheder for at indgå i dialogisk udveksling med hinanden - at sige »Du « til de andre. ${ }^{49}$ Sidst i 1997 blev der desuden afholdt et forskningsseminar i Fugls $\varnothing$ under titlen $»$ Folkeoplysning, krop og dannelse«. Overskriften for seminaret angav, at emnet nu for alvor havde bidt sig fast i den idrætshistoriske og kropskulturelle forskning, men også at feltet åbnede for mange spændende vinkler, der kunne bidrage til undersøgelserne. Således indeholdt den antologi fra 1998, som udsprang fra dette seminar, bidrag, der omhandlede gymnastik- og folkeoplysningshistorie, antropologiske udredninger vedr. ritualernes betydning, filosofi- ske overvejelser om spontaniteten som element i livsoplysningen, kulturteoretiske belysninger af kroppens betydning i de senmoderne udlejringsprocesser, betydningens naturhistorie, forholdet mellem kulturpolitik og folkeoplysning og fænomenologiske overvejelser vedrørende det relationelle som basis for den kropslige væren.

I 1999 kom endnu et udspil, der var rettet mod forholdet mellem folkeoplysning, krop og demokrati. Skriftet med titlen Demokrati og kropslighed var Gerlev-miljøets bidrag til dette emne. Her viderefører Ove Korsgaard et tema, der kort blev berørt i artiklen »Delingsføreruddannelse og demokratiuddannelse « fra 1997, nemlig spørgsmålet om demokratiet som symbolsk system og kroppens rolle heri. Især rettes opmærksomheden på overgangen fra enevælde til demokrati og den symbolske forskydning, der kan udtrykkes i kiasmen: »Fra magtens tale til talens magt $«{ }^{50} \mathrm{I}$ artiklen »Demokrati uden krop« forfægtes det synspunkt, at den politiske legitimitet $\mathrm{i}$ enevælden var bundet til kongens krop, kronen, kåben, det blå blod, arvefølgen og ritualerne. ${ }^{51}$ Kongen inkarnerede magten og havde i den forstand ikke behov for at sige noget, når han tronede frem. I den demokratiske politik er magten derimod ikke funderet i kroppen, men i talen. Magten kan kun udøves gennem talen og kun ved at henvise til noget andet end talerens egen krop. Dette »andet « blev i det moderne demokrati til folket og nationen, som udgjorde de nye abstrakte legitimeringsfigurer. Mens fyrsten udfyldte tronstolen, er demokratiet karakteriseret ved talerstolen, som kun er et midlertidigt standpunkt for den, der taler. For tales skal der; magtens sted er tomt og fyldes kun ud ved tale, af borgeren, der taler på andres vegne - altså repræsentation frem for inkarnation.

Med inspiration fra den franske filosof 
Olivier Mongin pointerer Korsgaard, at demokratiets »kropsløshed « og det »afkorporerede individ « har en bagside, idet man her fratages de selvindlysende relationer til andre, til samfundets store krop, hvor alt hænger sammen. ${ }^{52}$ Det demokratiske samfund skaber i den forstand små individuelle kroppe - og fremmedgørelse. Dette forhold har skabt tilbagevendende forsøg på at genetablere den store krop, det organiske samfund, hvor alle kender deres plads og underkaster sig en opløsning i massen. Disse fors $\varnothing \mathrm{g}$ kendes fra de totalitære systemer. For Korsgaard betyder det, at der ikke er nogen vej uden om: »I demokratiet er magten ikke forankret i kroppen, men i talen! . $^{53}$

Tiltroen til talen er et helt centralt omdrejningspunkt i demokratiet, men som Henning Eichberg bemærker i sin kritiske afslutningsartikel: »Også antidemokraten taler med ord « ${ }^{54}$ Endvidere påpeger Eichberg, at demokratiets »kropsløshed « er relativ - med demokratiet får individerne netop retten til deres egen krop, hvad Korsgaard også selv er inde på. At tale om omkorporalisering frem for afkorporalisering giver her mere mening. Med Foucault kunne man sige, at individerne først bliver individer, idet de udstyres med en krop i det politiske system. Demokratiet skaber derfor ikke »afkorporaliserede individer «, men giver i en vis forstand kroppen tilbage til folket.

I 2001 udkom der flere bøger med forholdet mellem oplysning, krop og demokrati som det helt centrale forskningsfelt. Forskningsprojektet »Voksenuddannelse, folkeoplysning og demokrati« blev afsluttet med udsendelsen af fire antologier, hvoraf den ene, Ove Korsgaard, Bo Vestergård Madsen og Niels Kayser Nielsen (red.): Idraet, krop og demokrati, var viet til dette emne. Heri inddrog også Troels Ras- mussen Hal Koch i sin artikel om Gymnastikhøjskolen ved Viborg med titlen $\gg$ Lederuddannelse og demokrati ${ }^{55}$ Artiklen er et bidrag til Gymnastikhøjskolens tidlige historie herunder forberedelsesfasen og oprettelsen i 1951. Det centrale spørgsmål for Rasmussen er, hvilken mening gymnastikken og kroppen er blevet tilskrevet i den oplysningspraksis, der har fundet sted - og hvilken demokratiforståelse, den har fordret.

Artiklen var en forløber for en bog om Gymnastikhøjskolen ved Viborg, der udkom i 2001 under titlen Lederuddannelse og demokrati. En gymnastikhøjskoles historie i forbindelse med skolens 50 -års jubilæum. ${ }^{56}$ Rasmussen går historisk til værks og analyserer den særegne blanding af patriarkalsk formynderskab og medborgerlig dannelse, som den danske højskole har baseret sig på, ligesom forholdet mellem gymnastikken og samtalen tages op som en demokratisk og folkelig udfordring. Skolens forstandere tildeles en betydelig plads i bogen, hvilket selvsagt er på sin plads, for så vidt som også Gymnastik- og Idrætshøjskolen ved Viborg er præget af både idræts- og højskoleverdenens trang til centrering omkring »store « ledere. Dette er selvsagt ikke uden betydning for det demokratiaspekt, som flankerer den idrætshistoriske vinkling.

Karakteristisk for dansk idrætshistorie i snæver henseende og nordisk samfundstænkning i det hele taget var der også i Viborg tale om et samarbejde mellem det offentlige, erhvervslivet og de folkelige kredse. Det fremgår ligeledes, at man fra Viborgs side ikke tog det så nøje, om der blev tale om en højskole eller en idrætshøjskole. Man fandt det heller ikke så afgørende, om der skulle lægges vægt på folkelig idræt eller konkurrencesport.

Troels Rasmussens bog bidrager til for- 
ståelse af den gymnastikverdenens folkelighed, der fandt sted i bl.a. Viborg. Den autoritære nisse fra Ollerup flyttede med, men måtte give uhjælpeligt tabt i løbet af 1960'erne. Det efterlod den folkelige del af samfundet med en orienteringsløshed, der siden skulle få politiske konsekvenser. Set $\mathrm{i}$ lyset heraf var det trist, at det blev en $\mathrm{Bu}-$ kh-elev som Mads Nielsen, der kom til at tegne billedet i Viborg. Spørgsmålet er imidlertid, om der var andre muligheder. Fra bykulturen var der ingen alternativer at pege på. I forbindelse med oprettelsen af Dansk Ungdomssamvirke havde Oskar Hansen (ham med »Danmark for Folket «) omtalt idrætsfolk som »aandelige Strandvaskere«. Det overlod idrætsverdenen til sådanne og til ikke så få folk på ledende poster, som havde en autoritær arv med fra de 1930'ere, hvor det var en vogue at kritisere både demokrati og parlamentarisme. Det er dette perspektiv, der peges på i Troels Rasmussens bog.

Det er netop en af de tidligere forstandere fra Viborg, Olav Ballisager, der sammen med Søren Damkjær har redigeret antologien Kroppens idé fra 2003. ${ }^{57}$ Blandt meget andet belyses også her den danske gymnastiktradition i artiklerne »Ide med kroppen« og »Hvad siger bevægelsen? « gennem overvejelser om »den villede æstetik«. Begrebet bliver brugt som afsæt til en diskussion og kritik af det kulturelle klima, som har været herskende i den folkelige gymnastik - enten har gymnastikken været anset som et middel i en større sags tjeneste eller også - som i de seneste årtier - er den blevet til »gymnatainment $\kappa^{58}$ I stedet tolker Olav Ballisager gymnastikhistorien ud det synspunkt, at gymnastikken skal udvikles kvalitativt, æstetisk, almenmenneskeligt for at blive oplysende. »Punktet udenfor « er ikke længere væk end én selv, som Claus Bøje har formuleret det $\mathrm{i}$ en anden sammenhæng. ${ }^{59}$ Udover disse bidrag skal nævnes den serie, som forlaget Klim har publiceret under titler Bevagelsesstudier. Dette djærve initiativ har foreløbig resulteret i seks værker, hvoraf tre skal omtales.

Bo Vestergård Madsens ph.d.-afhandling Oplysning i bevagelse - kultur, krop og demokrati i den folkelige gymnastik fra 2003 skriver sig ind i feltet vedrørende idræt, krop og demokrati, men tager mere radikalt end ellers set greb om et fænomenologisk og kropssociologisk aspekt som modvægt til den mere idéhistoriske tilgang. Forfatteren analyserer den folkelige gymnastikbevægelse fra 1928 til i dag i et oplysnings- og demokratiperspektiv med et tilbageblik til den svenske gymnastiks gennembrud i 1880'ernes højskolemiljø. Frem for at fremstille idrætsorganisationernes og samfundets »udvikling « er det bogens formål at anskueliggøre de spring i historien, som kommer til syne ved ændringerne i bevægelserne og den sproglige bearbejdelse af dem. Dermed bidrager afhandlingen til diskussionen om, hvorvidt samfundsændringer »sætter « sig på kroppen, eller om de idrætslige mønstre foregriber talen og de samfundsmæssige forskydninger. Bo Vestergård Madsen belyser bl.a. spændingen mellem de dygtige og de mange i bevægelsens selvforståelse og praksis. Der peges her på paradokset mellem den deltagelsesdemokratiske fordring og dyrkelsen af en elite. Her trækkes der tråde fra Niels Bukhs, Kristian Krogshedes og Erik Flensted-Jensens gymnastikturneer til nutidens Verdenshold, som under betegnelsen »den folkelige elite « tegner organisationen DGI. Også overgangen mellem kommandogymnastik, musikgymnastik og vore dages performancegymnastik analyseres. Det vises bl.a., at gymnastikken ikke længere handler om et budskab om at bidrage til en sag, men snarere kan anskues 
som en invitation om et være med i et fællesskab. Det er ikke lederens faste kommando, men gymnasternes flydende kontakt med publikum, der er i centrum. - Et billede på nye oplysnings- og demokratiformer? Afhandlingen kan overordnet ses som en hybridisering, der peger på en tredje vej, hvor bevægelsesbegrebet giver mulighed for nye indsigter - et bevægelsesbegreb, der både adresserer de kropslige udfoldelser, stemningen og organiseringen.

Henning Eichbergs bog i samme serie People of Democracy. Understanding SelfDetermination on the Basis of Body and Movement fra 2004 er, som overskriften angiver, et yderligere forsøg på at strukturere demokratispørgsmålet ud fra det tredelte bevægelsesbegreb. ${ }^{60}$ Eichberg tager et kropslig-materialistisk udgangspunkt for at belyse problemstillingen: Hvem er demokratiets folk? Forfatteren peger her på, at demokrati ikke kun kan ses som en abstrakt idé, der knytter sig til forskellige institutioner. Det har også at gøre med folkets og folks bevægelsespraksis. Gennem forskellige historiske nedslag søger Eichberg at vise, at demokratiet og dets stadige fornyelse er afhængig af et folk, der bliver til et folk i og med, at de bevæger sig sammen og manifesterer sig, går på gaden og påtager sig ansvaret: »Vi er folket «. I videre forstand er bogen et indlæg i debatten om folkebegrebets relevans og demokratiets stilling $\mathrm{i}$ forhold til nye politiske overbygninger. Eichberg fastholder vigtigheden af, at demokratiet har brug for et (bevægeligt) folk og omvendt - og at demokratiet ikke kan sikres, uden at folks identitetsmæssige forhold tages alvorligt.

Det seneste skud på stammen i Bevagelsesstudier er antologien Folk - om et grundbegreb i demokrati og kultur ligeledes fra 2004. Artiklerne beskæftiger sig dels analytisk, dels teoretisk med folkebe- grebets politiske, etniske, sociale og kropslige implikationer. Antologien er tilegnet Henning Eichberg og også her båret af ideen om, at der går noget forud for ideen om »folket«, nemlig bevægelse: »Folket bliver også til i fælles bevægelse «, hedder det i indledningen. ${ }^{61}$ Et folk er med andre ord ikke kun konstitueret af det bevidsthedsmæssige, som en del refleksivitetsforskere ellers påstår. Bevægelsesbegrebet er imidlertid flertydigt - og partikulært. Der kan med andre ord vanskeligt siges noget generelt og universalistisk om fænomenet »folk«. Folket bliver folk i kraft af, at det gør fælles sag, men altid i historisk og rumlig specificitet. Her går der med andre ord en lige linje tilbage til de tanker, der blev bragt på banen i dansk idrætshistorisk forsknings barndomsår i 1980'erne. Men nu altså med den væsentlige tilføjelse, at det ikke længere er idræt i snæver forstand, men idræt i samfundsmæssig kontekst, der er det centrale. Kampen om folket - titlen på Ove Korsgaards seneste bog, som blev indleveret som doktorafhandling ved DPU - er altså ikke slut. ${ }^{62}$ Heller ikke i en nordisk sammenhæng. Allerede i 2000 havde Svenska litteratursällskapet i Finland udgivet en antologi om folkebegrebet. ${ }^{63}$ Endnu en gang kan det konstateres, at danskerne ikke har opfundet folkebegrebet, og at vi heller ikke har patent på det, selvom det kan synes sådan i disse år, hvor begrebet er blevet revitaliseret $\mathrm{i}$ den politiske offentlighed.

\section{Afslutning}

Fra 1995 og frem er der, som det fremgår, stadig tale om en traditionel centrering omkring egentlig idrætshistoriske emner, og den organisatoriske og foreningsmæssige dimension påkalder sig stadig interesse; bl.a. betinget af, at her fortsat forestår 
store opgaver. Men det er samtidig tydeligt, at blandt de fire tendenser, der er peget på i det ovenstående, har ikke mindst den blok, der samler sig om krop, oplysning og demokrati, vind i sejlene og fremstår som et vigtigt forskningsfelt. ${ }^{64}$ Dansk idrætshistorisk forskning flytter sig hurtigt i disse år. Man må håbe, at bukserne holder, og at de mange teoretiske armbøjninger ikke går ud over den empiriske fordy- belse. Hvad angår konkrete unders $\emptyset$ gelser er der nemlig stadig meget at gøre. Imidlertid kan man samtidig glæde sig over, at den tilstand, der var fremherskende for år tilbage, hvor det var en lille håndfuld af Tordenskjolds soldater, som tegnede billedet, nu synes at være overvundet. Der er kommet nye, lovende forskere til, hvad ikke mindst rækken af specialer og ph.d.afhandlinger vidner om.

\section{Noter}

1 Ove Korsgaard: Kampen om kroppen. Dansk idrats historie gennem 200 år. København: Gyldendal 1986.

2 Jens, Krogslund: J.C.F. Gutsmuths og hans samtid. Gymnastik-historiske kilder, bind I. Odder: Gymnastik-Historisk Forlag 1982 og Nogle rids af Linggymnastikkens for-historie i Danmark. Gymnastikhistoriske kilder, bind II. Odder: Gymnastik-Historisk Forlag/HH grafisk tegnestue 1987.

3 Se Peter Arentzen og Else Trangbæk: Rapport fra idratshistorisk seminar d. 7.-8. oktober 1983 på Danmarks Højskole for Legemsфvelser. København: DHL 1983.

4 Se Niels Kayser Nielsen: »Kvalificering gennem knægtelse«. I: Centring, nr. 3-4/1982 s. 205 og 207.

5 Ove Korsgaard: Kampen om kroppen. Dansk idrats historie gennem 200 år. København: Gyldendal 1986 s. 9.

6 Ibid. s. 12.

7 Else Trangbæk, mfl.: »Indledning«. I: Else Trangbæk, mfl. (red.): Dansk idratsliv. København: Gyldendal 1995.

8 Bo Vestergård Madsen: Oplysning i bevagelse kultur, krop og demokrati $i$ den folkelige gymnastik. Århus: Klim 2003 og Niels Kayser Nielsen: Fra Robin Hood til fodbold. Et kulturanalytisk studie i arbejderklassens kropskultur $i$ England i 1800-tallet. Odense: Odense Universitetsforlag 1992.

9 Red.: »Forord«. I: Idratshistorisk Årbog 1985. Odense: Odense Universitetsforlag 1985 s. 7.

10 Jan Lindroth: »Årsbokstankar vid ett tioårsjubileum«. I: Idratshistorisk Årbog 1994. Odense: Odense Universitetsforlag 1995 s. 19.
11 Mindre studier er det dog blevet til. Se: Bjarne Ibsen og Bente Sørensen: »Idrættens organisationer - struktur, problemer og selvopfattelse«. I: Jacob A. Buksti, (red.): Organisationer under forandring. Studier i organisationssystemet i Danmark. Århus: Forlaget Politica 1980 samt Finn Berggren, Bjarne Ibsen og Ejgil Jespersen: Idrattens trakfugle. Instruktфruddannelse og instruktфrarbejde i folkelig idrat. Vejle: DDGU 1987 s. 5-30.

12 Jørn Hansen: »Fusioner - Danske gymnastik- og Idrætsforeninger - Danmarks Idræts-Forbund. Et historisk essay«. I: Idratshistorisk Årbog 1994. Odense: Odense Universitetsforlag 1995.

13 Ib Nordby: Sablen og den blфde hat. De danske skytte-, gymnastik- og idratsforeningers forhold 1940-45 med et indledende historisk tilbageblik. Odense: Odense Universitetsforlag 1995 s. 156.

14 Klara Aalbæk Korsgaard: Anna og Jørgine. En historisk fortalling om to kvinder, deres gymnastik og deres højskole. Odense: Odense Universitetsforlag 1996.

15 Jørgine Abildgaard: Øvelser til Kvindegymnastik. Snoghøj 1928 s. 8.

16 Jørn Hansen: Ikke at syne, men at vare. Sфnderjydsk idrat gennem 100 år. Odense: Syddansk Universitetsforlag 2003.

17 Verner Bruhn: Det skæve træ. Træk af ungdomsforeningernes og gymnastikforeningernes historie efter 1945. Vejle: DGI 1997.

18 Per Jørgensen: Ro, renlighed, regelmassighed. Dansk Idrats-Forbund og sportens gennembrud ca. 1896-1918. Odense: Institut for Idræt 1996.

19 Ivar Berg Sørensen og Per Jørgensen (red.): »Een Time dagligen" - skoleidrat gennem 200 år. Odense: Odense Universitetsforlag 1998. 
20 Jørn Hansen: Ringene samles - En fortalling om den olympiske bevagelse. Odense: Syddansk Universitetsforlag 2004.

21 Ole Skjerk: Dameudvalgets inderlige Overflфdighed. Kvindehåndbold $i$ Danmark 1900-1950. København: Institut for Idræt, Københavns Universitet 2001.

22 Sine Agergaard: Århus: At viderefфre traditionerne - En etnografisk komparativ analyse af to danske idratsuddannelser for folkelige ledere og elitetranere. Århus: Afdeling for Antropologi og Etnografi, Aarhus Universitet 2004.

23 Se bl.a. Niels Kayser Nielsen: »Sport og bondekultur - om foreningsliv i provinsen i mellemkrigstiden«. I: Fortid og Nutid, nr. 1/1995.

24 Niels Kayser Nielsen: »Foreningskrise i mellemkrigstiden - om ungdom og idræt på landet «. I: Idratshistorisk Årbog 1994. Odense: Odense Universitetsforlag 1995 s. 31.

25 Poul Porskær Poulsen: »Det var Ungdom og Kræfter, Styrke og Vilje« - gymnastik og skyttesag på Silkeborg-egnen og i Gødvad ca. 1868-1930«. I: Østjysk Hjemstavn 1996.

26 Poul Porskær Poulsen: »Fra sandbakkerne til idrætsparken - Vejle Lawn Tennis Klubs første år«. I: Vejlebogen 2000.

27 Johnny Wøllekær: Odense i bevagelse - strejftog $i$ byens idratshistorie. Byhistorisk Udvalg og SIKO 2001. Se også Johnny Wøllekær: Da sporten kom til byen - En historisk-empirisk undersøgelse af sportens gennembrud $i$ Odense ca. 1860-1920. Odense: Stadsarkivet i Odense 2001.

28 Morten Mortensen: Idrat som kommunal velfard. Mentalitet, velfard og idratspolitik $i$ Kobenhavn, Ballerup og Skive 1870-1970. København: Institut for Idræt 2004.

29 Niels Kayser Nielsen: »Alting har sin tid - idrættens afsked med 1900-tallet «. I: Carsten Hauerberg (red.): Idratshфjskolen i Sфnderborg. Udgivet $i$ anledning af skolens 50 års jubilaum 15. maj 2002. Sønderborg: IHS 2002 s. 30.

30 Hans Bonde: Niels Bukh. En politisk-ideologisk bibliografi. København: Museum Tusculanums Forlag 2001.

31 John T. Lauridsen: »Disputatsopposition - Niels Bukh som politiker og ideolog«. I: Historie 2/2001 og Hans Bonde: »Replik til John T. Lauridsens opposition«. I: Historie 1/2002.

32 Se Niels Kayser Nielsen: »The Cult of the Nordic Superman - between the pre-modern and the Modern«. I: The Sports Historian, nr. 1/1999 s. 77.

33 Else Trangbæk: »Gender in Modern Society: Femi- ninity, Gymnastics and Sport« I: Henrik Meinander \& J.A. Mangan (eds.): The Nordic World. London: Frank Cass 1998. Se desuden Jørn Hansen: »Politics and Gymnastics in a Frontier Area post1848« og Per Jørgensen: »From Balck to Nurmi: The Olympic Movement and the Nordic Nations.

34 Se også: »Hvis kvinder var normen? Idrættens kvindehistorier «. I: Forum 2/1995 og Else Trangbæk \& Arnd Krüger (eds.): Gender \& Sport from European Perspectives. London: CESH 1999.

35 Se Ole Skjerk og Anne Lykke Poulsen: »Ikke paa Pigekammeret - men på førersædet«. I: Idratshistorisk Årbog 1997; Anne Lykke Poulsen (red.): Kvindeliv-idratsliv: kvindegymnastik i Danmark 1850-2000. Århus: Kvindemuseet i Danmark 1998.

36 Anne Lykke Poulsen: »En kamp om kvindelighed «. I: Dansk Sociologi 2/2004.

37 Rune Slagstad: De nasjonale strateger. Oslo: Pax Forlag 1998 s. 212 ff.; Matti Goksøyr: »Strateger på banen, lagspillere på sidelinjen?«. I: Erik Rudeng (red.): Kunskapsregimer. Debatten om De nasjonale strateger. Oslo: Pax 1999.

38 Johan Norberg: Idrottens väg till folkhemmet studier i statslig idrottspolitik 1913-1970. Stockholm: SISU idrottsböcker 2004.

39 Henning Eichberg: »Nationalism and the Culture of the Body: The Politicization and »Popular« Gymnastics in the Nineteenth-Century Denmark «. I: The International Journal of the History of Sport 2/1995.

40 Ove Korsgaard: Kampen om lyset. Dansk voksenoplysning gennem 500 år. København: Gyldendal.

41 Ibid. s. 469.

42 Ove Korsgaard: »Delingsføreruddannelse og demokratiuddannelse «. I: Ove Korsgaard (red.): Antologi om den frivillige sektor. Vejle: DGI Forskning 1997. Se også: »Delingsføreruddannelse og demokratiuddannelse - et stykke højskolehistorie«. I: Vartovbogen 1997 s. 62 f. Artiklen blev trykt også i forskningsprojektet »Voksenuddannelse, folkeoplysning og demokrati (VFD) «s arbejdspapirserie som nr. 2. Den kropslige dimension blev således tidligt introduceret i projektet. Se Ove Korsgaard: Delingsføreruddannelse og demokratiuddannelse/Disciplinering, subjektivering og demokrati. VFD, arbejdspapir nr. 2. København: Forskningscenter for Voksenuddannelse, Danmarks Lærerhøjskole 1998; Bo Vestergård Madsen: Kultur, krop og demokrati. Arbejdspapir nr. 4; Niels Kayser Nielsen: Demokrati, krop og velfard. Arbejdspapir nr. 7. 
43 Ove Korsgaard: »Delingsføreruddannelse og demokratiuddannelse - et stykke højskolehistorie «. I: Vartovbogen 1997 s. 62.

44 For en historisk gennemgang se Poul Nyboe Andersen: Hal Koch og Krogerup Hфjskole. Odense: Odense Universitetsforlag 1993.

45 Ove Korsgaard: »Delingsføreruddannelse og demokratiuddannelse - et stykke højskolehistorie «. I: Vartovbogen 1997 s. 66.

46 Ibid. s. 67. Jf. desuden Niels Kayser Nielsen: »Dekadence og vitalitet - om idrætten og den kollektive mentalitet i tiden omkring $1900 \ll$. I: Niels Kayser Nielsen (red.): Håndbold $i 100$ år - et overblik. København: DHFs Forlag 1997.

47 Niels Kayser Nielsen: »Kroppen som demokratisk anliggende - i en nordisk kontekst «. I: Historie $1 / 2002 \ll$.

48 Henning Eichbergs »Otherness in Encounter. Thinking Folk Identity, Democracy and Civil Society with the Help of Martin Buber«. I: Ove Korsgaard, (ed.): Adult Learning and the Challenges of the Twenty-First Century. Association for World Education, S.I. Odense: Odense University Press 1997.

49 Martin Bubers hovedværk »Ich und Du« fra 1923 blev første gang oversat til dansk i 1964. I 1997 udkom en 3. udgave, som var en nyoversættelse. Se Martin Buber: Jeg og Du. København: Hans Reitzels Forlag 1997.

50 Ove Korsgaard: »Demokratiet uden krop«. I: Henning Eichberg mfl. (red.): Demokrati og kropslighed. Slagelse: Bavnebanke 1999 s. 39.

51 Her trækker Korsgaard på den politiske filosof Claude Lefort og historikeren Jan Ifversen. Se bl.a. Claude Lefort: »Spørgsmålet om demokratiet«. I: Slagmark 13/1989; Jan Ifversen: »Den franske revolution mellem demokrati og ideologi«. I: Slagmark 13/1989 og Jan Ifversen: Om magt, demokrati og diskurs - diskuteret i lyset af den franske revolution. Begrebshistoriske studier II. Århus: Det begrebshistoriske Netværk 1997.

52 Se Olivier Mongin: »Demokratiet uden krop«. I: Paradigma 1/1989.
53 Ove Korsgaard: »Demokratiet uden krop«. I: Henning Eichberg mfl. (red.): Demokrati og kropslighed. Slagelse: Bavnebanke 1999 s. 45.

54 Henning Eichberg: »Demokratiets højskole og kroppens højskole«. I: Henning Eichberg mfl. (red.): Demokrati og kropslighed. Slagelse: Bavnebanke 1999 s. 115.

55 Troels Rasmussen: »Lederuddannelse og demokrati $\ll$. I: Ove Korsgaard, Bo Vestergård Madsen og Niels Kayser Nielsen (red.): Idrat, krop og demokrati. København: Gads Forlag 2001.

56 Rasmussen, Troels: Lederuddannelse og demokrati. En gymnastikhфjskoles historie. Odense: Odense Universitetsforlag 2001.

57 Olav Ballisager og Søren Damkjær (red.): Kroppens idé. Århus: Systime 2003.

58 Begrebet er Per Skrivers, cit. i Olav Ballisager: »Hvad siger bevægelsen?«. I: Olav Ballisager og Søren Damkjær (red.): Kroppens idé. Århus: Systime 2003 s. 245.

59 Claus Bøje: »Det uformulerbare - Kropsfagene i højskolen. I: Else-Marie Boyhus (red.): Midt $i$ hфjskolen. København: Gyldendal 1991.

60 Henning Eichberg: People of Democracy. Understanding Self-Determination on the Basis of Body and Movement. Århus: Klim 2004.

61 Jørn Møller: »Indledning«. I: Jørn Møller (red.): Folk - om et grundbegreb i demokrati og kultur. Århus 2004 s. 7.

62 Ove Korsgaard: Kampen om folket. Et dannelsesperspektiv på dansk historie gennem 500 år. København: Gyldendal 2004.

63 Fewster, Derek (red): Folket-Studier i olika vetenskapers syn på begreppet folk. Helsingfors: Svenska litteratursällskapet i Finland 2000.

64 Se også Inge Adriansen: »Idrætten i det nationales tjeneste « og Niels Kayser Nielsen: »Alting har sin tid - idrættens afsked med 1900-tallet «. I: Carsten Hauerberg (red.): Idratshфjskolen i Sфnderborg. Udgivet $i$ anledning af skolens 50 års jubilaum 15. maj 2002. Sønderborg: IHS 2002. 